\title{
Brief review: lignocellulolytic enzymes from polypores for efficient utilization of biomass
}

\author{
Nguyen KA, Wikee $S$ and Lumyong $S^{*}$
}

Department of Biology, Faculty of Science, Chiang Mai University, Chiang Mai 50200, Thailand

Nguyen KA, Wikee S, Lumyong S 2018 - Brief review: Lignocellulolytic enzymes from Polypores for efficient utilization of biomass. Mycosphere 9(6), 1073-1088, Doi 10.5943/mycosphere/9/6/2

\begin{abstract}
Polypores are a group of diverse macrofungi that belong to phylum Basidiomycota (Basidiomycetes). The ability of polypores to produce enzymes has attracted the attention of scientists. These enzymes are increasingly being used for many industrial purposes, e.g. textile, pulp and paper, food, detergents and animal feeds. However, their expensive of production is the main hindrance to their use. Fortunately, most polypores can decompose cellulose, hemicellulose, and lignin in the plant cell walls. Solid state fermentation is a good method to degrade lignocellulose and to produce enzymes at low cost since residual agro-industrial waste can be used as the substrate for microorganism growth. Every day large amounts of residues and waste materials are lodged into the environment by industry, agriculture, and other ways leading to environmental problems. The present paper explores the isolation of polypore fungi and their production of lignocellulolytic enzymes, taking full advantage of various agro-industrial wastes as substrate.
\end{abstract}

Key words - Agro-industrial wastes - Cellulolytic - Fermentation - Fungi - Ligninolytic

\section{Introduction}

Enzymes are proteins that are produced by living cells. They are catalysts which control biochemical processes (Robinson 2015). Being proteins, enzymes are biodegradable and can have activity in a wide range of $\mathrm{pH}$ values and at ambient temperatures (Gupta 2016). Lignocellulolytic enzymes include two groups; the ligninolytic enzymes which contain peroxidases and oxidases, and the cellulolytic enzymes such as cellulases, hemicellulases, xylanases. Lignocellulolytic enzymes have important industrial and environmental applications. The cost of enzyme production could be significantly lowered by utilizing low-value biological substrates such as agricultural waste (Bharathiraja et al. 2017).

Being a key factor in lignocellulose degradation, lignocellulolytic enzymes such as cellulase and hemicellulase are well known for their applications in various processes. Agriculture biomass wastes contain cellulose, hemicellulose and lignin (Table 1) with smaller amounts of pectin, protein, extractives and ash (Bajpai 2016).

Polypores (basidiomycetes) are a polyphyletic group of wood decaying fungi that are diverse in ecological specificity and morphological characteristics. Most polypores are capable of breaking down lignocellulose, and consequently they play a mainstay role in nutrient recycling in forest ecosystems. Although some polypores can cause tree disease (Ginns 2017), others have medicinal properties (Jayachandran et al. 2017). China possesses the highest polypore diversity in the world with 704 species, belonging to 134 genera, 22 families and 11 orders (Liwei \& Yucheng 2013). In 
North America 146 genera and 492 species of polypores have been recorded (Zhou et al. 2016). In Seoul, Korea, during 2008-2012, 300 specimens with poroid basidiocarp were collected (Jang et al. 2014). As of 2011, 360 Polyporales species from 18 families were recorded in Thailand (Chandrasrikule et al. 2011). Since then, additional polypore fungi have been discovered such as Polyporus thailandensis, Ceriporia cystidiata, Macrohyporia dictyopora, Perenniporia sp., and Ganoderma sichuanense (Kozue et al. 2016, Ponlada et al. 2016, Ji et al. 2017, Thawthong et al. 2017).

Table 1 Cellulose, hemicellulose, and lignin content in various lignocellulosic biomass

\begin{tabular}{lllll}
\hline $\begin{array}{c}\text { Lignocellulosic } \\
\text { biomass }\end{array}$ & Cellulose (\%) & Hemicellulose (\%) & Lignin (\%) & References \\
\hline Corn cobs & $33.7-41.2$ & $31.9-36$ & $6.1-15.9$ & $\begin{array}{l}\text { Isikgora \& Becer } \\
\text { Wheat straw }\end{array}$ \\
Corn stover & 37.7 & 14.8 & 23.5 & Santos et al. (2015) \\
Rapeseed & 51.3 & 22.7 & 18.6 & Kim et al. (2016) \\
Bagasse & $25.0-45.0$ & $28.0-32.0$ & 44 & Pei et al. (2016) \\
Corn pericarp & 22.5 & 23.7 & $15.0-25.0$ & Putro et al. (2016) \\
Grasses & $25.0-40.0$ & $25.0-50.0$ & 4.7 & Kim et al. (2017) \\
Rice husks & $25.0-35.0$ & $18.0-21.0$ & $10.0-30.0$ & Kumar \& Sharma \\
Banana peels & 9.90 & 41.38 & $26.0-31.0$ & Wikee et al. (2017) \\
Soya straws & 44.2 & 5.9 & 8.90 & Kabenge et al. (2018) \\
Paddy straw & $34.8-36.4$ & $23.65-30.3$ & 19.2 & Kim (2018) \\
& & & $10.4-11.0$ & Syazwanee et al. \\
\end{tabular}

\section{Ligninolytic enzymes}

Ligninolytic enzymes are elaborated in the utilization and degradation of the complex polymer of lignin as long carbon chain. They involve mainly oxidative enzymes such as laccase (Lac), lignin peroxidase (LiP), and manganese peroxidase $(\mathrm{MnP})$. In recent years, the market for ligninolytic enzymes has risen because of their application in biotechnological areas and their wide use in pollution treatment, for example, degradation of hazardous compounds such as dyes, phenols and xenobiotic (Niladevi et al. 2009). Lignin is a large complex macromolecule which contains three monomers (p-coumaryl alcohol, coniferyl alcohol and sinapyl alcohol) and represents lignocellulosic biomass of approximately 15-25\% (Davin \& Lewis 2005). In the past 10 years, Thai researchers have become interested in screening and production of lignolytic enzymes from fungi, and research has shown good results. Zecarias et al. (2016) screened ligninolytic enzymes by dye decolorization plate test, with 49 of 61 fungal strains showing decolorizing activity. Vaithanomsat et al. (2010) produced ligninolytic enzymes (Lac and MnP but not LiP) by a white-rot fungus Datronia sp. KAPI0039 (Vaithanomsat et al. 2010). Aryl alcohol oxidase (AAO, EC 1.1.3.7) and glyoxal oxidase (GLOX) are accessory enzymes, which take part in lignin degradation. These enzymes are involved in hydrogen peroxide $\left(\mathrm{H}_{2} \mathrm{O}_{2}\right)$ production (Tuomela \& Hatakka 2011).

\section{Laccases}

Laccases (EC 1.10.3.2) are a group of multi-copper enzymes also known as benzenediol, with oxygen oxidoreductase or p-diphenol oxidase belonging to the oxidoreductase class. The reaction of laccase takes place one oxygen molecule was oxidized to water associated with one electron. Oxidation ability of laccase includes a broad range of substrate such as aromatic amines, methoxysubstituted monophenols (Bourbonnais et al. 1995) and polyphenols (Bourbonnais \& Paice 1990). This oxidation generates oxygen-centered free radicals that could be converted to quinine in a second enzyme catalyzed reaction (Gianfreda et al. 1999). 
Most species of white rot fungi produce laccase to varying degree (Khushal et al. 2010). Laccases play an important role in various industries with applications in cosmetics, food, paper, pulp, textile, synthetic chemistry, environment treatment and pollutant removal agent (e.g., soil bioremediation), biodegradation of phenolic pollutants and removal of endocrine disruptors (Couto $\&$ Toca 2006). A variety of agricultural materials have been used for laccase production such as banana peel, bamboo pulp, coffee husks, corn cobs, corn stover, rice husk, rice straw, rice bran, orange peel, and sugarcane bagasse. Research has shown that orange peel is the best substrate for laccase production (Chairin et al. 2013, 2014). Laccase enzymes from polypores have been studied for a long period, especially from common genera such as Trametes, Stereum, and Phanerochaete. Besides these widespread fungi, laccase from Pycnoporus cinnabarinus was reported as the only ligninolytic enzyme produced by this species (Khushal et al. 2010). Trametes versicolor was found to produce laccase on the third day of cultivation (Osma et al. 2011). Ganoderma lucidum has been used as phenolic and metallic inducers to optimize laccase production (Kuhara \& Papinutti 2014).

\section{Lignin peroxidase $(\mathrm{LiP})$}

Lignin peroxidase (EC 1.11.1.14), commonly known as ligninase, is one of the most important enzymes involved in the utilization of lignin. Both phenolic and non-phenolic compounds can be oxidized by cleaving the propyl side chain of lignin substructures (Schoemaker et al. 1985) and this enzyme has been shown to depolymerize lignin in vivo (Hammel et al. 1993). Oxidation of nonphenolic compounds by lignin peroxidase with a relatively high redox potential have been interpreted by several authors as the result of an unusually high redox potential of the oxidized enzyme intermediates, which are lignin peroxidase compound I (LiPI) or compound II (LiPII) (Hans \& Klaus 1996). The enzyme is also able to stabilize the initial product of veratryl alcohol oxidation, the veratryl alcohol radical cation (Valc+.).

Until recently, LiP enzymes had been reported from only a few white rot fungal genera such as Bjerkandera, Phanerochaete, Phlebia, and Trametes (Floudas et al. 2012, Duenas et al. 2013, Riley et al. 2014). Recently, different polypore fungi such as Ganoderma lucidum, Phanerochaete chrysosporium, and Bjerkandera adusta (Kadri et al. 2017, Shaheena et al. 2017, Bouacem et al. 2018), as well as the less studied Podoscypha elegans (Agrawal et al. 2017) have been more extracted in lignin peroxidase production ability.

\section{Manganese peroxidase $(\mathrm{MnP})$}

Manganese peroxidase (EC 1.11.1.13) is an enzyme produced by the lignin degraders. MnP shows a strong preference for $\mathrm{Mn}$ (II) as its reducing substrate. The redox potential of the $\mathrm{MnP}-\mathrm{Mn}$ system is lower than that of LiP and normally it does not oxidize non-phenolic lignin models (Glenn \& Gold 1985). Generally, lignin polymer provides strength to all higher plants and the natural function of MnP is the degradation of the matrix complex (Sundaramoorthy et al. 1997).

Previous research has suggested that MnP producing polypore fungi such as Phanerochaete chrysosporium, T. versicolor, Dichomitus squalens, Stereum ostrea, and Irpex lacteus. Sukarta \& Sastrawidana (2014) used agricultural waste to increase production of MnP by Polyporus sp. The ability to produce $\mathrm{MnP}$ by Phlebia especially the $P$. radiata group, which produced the highest levels, was shown by Kuuskeri et al. (2015). Mali et al. (2017) asserted that $P$. radiata was the strongest producer of manganese peroxidase when evaluated alone, as well as in co-culture and also Trichaptum abietinum.

\section{Cellulolytic enzymes}

Cellulolytic enzymes are regularly produced by a wide range of fungi and include cellulases, hemicellulases, pectinases, chitinases, amylases, proteases, phytases and mannases. Fungal cellulolytic enzymes are a group of hydrolytic enzymes responsible for cellulolytic and xylanolytic activities (Mtui 2012). 


\section{Cellulases}

Cellulases are enzymes that convert cellulose into simple sugars (Chinedu et al. 2005). They are able to hydrolyze $\beta-1,4$ linkages in cellulose chains and are produced by microorganism and animals (Henrissat 1991). The production rate of cellulase from fungi is higher compared to other microorganisms and this can be advantageous (Rana \& Kaur 2012). Based on their amino acid sequences and crystal structures, the catalytic modules of cellulases have been classified into numerous families (Henrissat 1991). Generally, complete cellulose hydrolysis is responded by three main types of cellulases combinations: endoglucanases, exoglucanases, and $\beta$-glucosidase (Zhang $\&$ Lynd 2006). These enzymes are widely used in numerous application areas including beverage, agriculture, paper, textiles, detergent, animal feed as well as an alternative for generating energy. Some organic compounds are inducers for cellulase such as disaccharides, spent ammonium sulphite liquor (Han et al. 2017), and glycerol (Delabona et al. 2016). The production of exoglucanase and $\beta$ glucosidase was induced from the co-culture of Trichoderma viride and Ganoderma lucidum in solid state fermentation (Afzal et al. 2014).

\section{Endoglucanases}

Endoglucanase (commonly called CMCase) randomly cut at the $\beta-1$, 4-bonds position of cellulose chains and generate new ends for other cellulase combinations to work on. In general, fungal endoglucanases hold a catalytic module with or without a carbohydrate-binding module, while bacterial endoglucanases may retain multiple catalytic modules, carbohydrate-binding modules, and other modules with unknown function (Xiao et al. 2013).

\section{Exoglucanases}

Exoglucanases are active at the reducing or non-reducing-ends of cellulose polysaccharide chains, which are then converted to major products either cellobiose or glucose. Exoglucanases work efficiently on microcrystalline cellulose by possible cracking cellulose chains from the microcrystalline structure (Teeri 1997).

\section{$\beta$-glucosidase}

$\beta$-glucosidase or $\beta$-D-glucoside glucohydrolase works by degradation of polysaccharides to provide monosaccharide units. These can then be absorbed and used by the organism to hydrolyze short-chain oligosaccharides and soluble cellobiose into glucose. Increasing the length of the cellulose chain causes loss of activity and also performs the hydrolysis of terminal $\beta$-D-glucose oligosaccharides as well as biosynthesis of oligosaccharide unit in glycoproteins or glycolipids (Melo et al. 2006). The complex cellulolytic enzymes have a better yield than the individual action when working together (Castro \& Pereira 2010).

\section{Xylanases}

The synergistic action of xylanase is required for maximizing hydrolysis of lignocellulosic residues (Ghose \& Bisaria 1979). The major enzymes are responsible for the endohydrolysis of $(1 \rightarrow 4)-\beta$-D-xylosidic linkages in xylans and random endohydrolysis of $(1 \rightarrow 3)-\beta$-D-glycosidic linkages in $(1 \rightarrow 3)-\beta$-D-xylans. Xylanases are synthesized by many types of microorganisms, marine algae, insects, seeds, etc. but the main source of commercial xylanases is filamentous fungi (Nair \& Shashidhar 2008, Dhillon et al. 2011, Chanwicha et al. 2015, Behnam et al. 2016, Amorim et al. 2017). The extracellular xylanase along with several accessory xylanolytic would be released into the medium for disbranching substituted xylans which is one composition in hemicellulose during fungal cultivation. There is significant interest in xylanolytic enzymes for their use as a supplement in animal feed, manufacture of bread, food, textiles, pulp bleaching and in the production of ethanol and xylitol (Polizeli et al. 2005). In Thailand, xylanase has been produced by an endophytic fungus Alternaria alternata on biomass substrate (Wipusaree et al. 2011), as well as the overexpression and gene transformation of xylanase by $X y l B-2 A$ gene on Pichia pastoris (Roongsawang et al. 2010). A variety of materials have been used for induction of xylanases including pure xylan and xylan-rich 
natural substrates, such as sawdust, corn cob, wheat bran, sugar beet pulp, and sugarcane bagasse (Maheshwari et al. 2000).

\section{History of polypores lignocellulolytic enzymes}

Table 2 Recent research on lignocellulolytic polypore fungi

\begin{tabular}{lcccccl}
\hline \multirow{2}{*}{ Polypore } & \multicolumn{5}{c}{ Enzymes } & \multicolumn{1}{c}{ References } \\
\cline { 2 - 6 } & Laccase & MnP & LiP & Cellulase & Xylanase & \multicolumn{1}{c}{} \\
\hline Ganoderma australe & + & + & + & + & & Chuwech \& Nuansri 2015 \\
Phlebia radiata & + & + & & + & & Jaana et al. 2015 \\
Hexagonia hirta & + & & & & & Kandasamy et al. 2016 \\
Trametes sp. & + & & & + & + & Bisht et al. 2017 \\
Cerrena unicolor & + & + & & & & Elisashvili et al. 2017 \\
Ganoderma sp. & + & + & & & & Farradá et al. 2017 \\
Rigidoporous lignosus & + & + & & & & Kantharaj et al. 2017 \\
Irpex lacteus & & & & + & + & Metrevelia et al. 2017 \\
Trametes versicolor & + & + & + & & + & Thiribhuvanamala et al. 2017 \\
\hline
\end{tabular}

Bourquelot \& Herissey (1897) investigated enzymes from the supernatant of Polyporus sulphureus and in 1899, Czapek discovered the lignin-degrading enzyme in Merulius lacrymans. In 1906, Buller published a list of enzymes present in the expressed fluid of young fruit bodies of Polyporus squamosus growing in nature. In recent years enzymes have been extracted from polypores. Ana et al. (2007) reported laccase production by Trametes versicolor, while Vladimir (2008) extracted lignocellulolytic enzymes from Lentinus edodes. MnP from Bjerkandera adusta was found to be more active than laccase, with much higher MnP activity observed in the culture degrading system (Eichlerová et al. 2007). High laccase activity, but neither MnP nor LiP, was detected in the culture systems of Coriolus versicolor cf. antarcticus (Levin et al. 2004). Similar results, with high levels of laccase activity but low levels or the absence of MnP and LiP, have been reported by Hatakka (1994), Nyanhongo et al. (2002) for several other ligninolytic white-rot fungi such as Trametes modesta, Junghuhnia separabilima and Dichomitus squalens. Levin et al. (2007) found that after 14 days Pycnoporus sanguineus reduced the lignin content of loblolly pine (Pinus taeda) chips by $11 \%$. Other species, Coriolopsis rigida, C. versicolor var. antarcticus, Peniophora sp., Phanerochaete sordida, Steccherinum sp., Trametes elegans and Trametes villosa had lesser effects on lignin reduction. Jo et al. (2011) established that $\beta$-glucosidase had more elements than the others for Ganoderma neo-japonicum and G. lucidum. For comparison, G. neo-japonicum had strong $\beta$-glucosidase activity and also an ability to produce cellulase (Jo et al. 2011). Fomes fomentarius had high activities of both laccase and $\mathrm{MnP}$, and also of celobiohydrolase and 1, 4- $\beta$ glucosidase while Fomitopsis pinicola produced elevated endoglucanase activity (Tomas et al. 2012). Lignin-degrading peroxidases of Bjerkandera adusta, Phlebia brevispora and a member of the Ganoderma lucidum complex were investigated by Duenas et al. (2013). The lignolytic and lignocellulosic enzymes of Ganoderma lucidum were studied by Sasidhara \& Thirunalasundari (2014). The results from this research enabled the conclusion that Ganoderma lucidum is a good candidate for scale-up production of ligninolytic and lignocellulosic enzymes (Duenas et al. 2013, Sasidhara \& Thirunalasundari 2014).

\section{Solid state fermentation}

Solid state fermentation (SSF) is a solid matrix that contains less water, hence microbial culture must develop on the surface and within the solid matrix (Barrios 2012, Simeng et al. 2015). Although water is essential for growth of microorganisms, in SSF water can be adsorbed on the solid support or solid matrix. Except for bacteria, SSF is a friendly fermentation and approximates the microorganisms living conditions. Fungi typically grow in nature on solid substrates such as wood, 
seeds, as well as dried parts of animals in low moisture condition (Hesseltine 1977). According to Robinson et al. (2001) the benefits of SSF over submerged fermentation (SmF) are high productivity in a brief period, better oxygen circulation, SSF approximates the living environment of the filamentous fungus, there is less downstream processing and wild-type strains of microorganisms can effectuate favorable, energy saving and reduce cost. However, in SSF, process control and scalingup is more slow-paced than with SmF. At least two types of applications are interested in SFF, lignocellulolytic enzymes production and lignocellulose degradation by itself (Singhania et al. 2010). Solid state fermentation is mainly used for traditional food processing and for fungal enzyme production. Since SSF more closely matches the natural habitat, then enzyme production at the commercial level has been successful with impulse enzyme secretion from fungi (Singhania et al. 2010). In Asian countries, humans have used SSF from ancient times to produce specific products such as "koji" and "sake". Contrary, in Western countries for the development of penicillin it was shown that $\mathrm{SmF}$ is a model technology for fermentation (Pandey 1992). Holker et al. (2004) compared SSF and SmF and concluded that SFF supplies higher volumetric productivities, the substrate is less inhibited, it yields enzymes with a higher temperature, $\mathrm{pH}$ stability, and time required is shorter. Roy et al. (2006) reported that for rubber biodegradation, SSF was a better treatment method than SmF. Pérez et al. (2003) showed a detail comparison between the two methods (Table $3)$.

\section{Lignocellulolytic enzyme application}

\section{Wine and brewing industry}

In food industry, wine stabilization is the main application of ligninolytic enzymes like laccases (Minussi et al. 2002). In wine production, it is necessary to remove polyphenols because of their unwanted effects and organoleptic features. Many treatments have been used to control this problem, such as enzyme inhibitors, complicated agents, and sulfate compounds to excommunicate discoloration, evaporation and flavour changes. Fortunately, these effects can be prevented and stabilizing beverages can be accomplished through use of laccase (Morozova et al. 2007). In wine production, enzymes improve colour extraction, clarification, and filtration and take full responsibility for quality and stability, for example, amylase, amyloglucosidase, cellulase, glucanases, hemicellulases, pectinases, glucanases, and hemicellulases (Singh et al. 2007, Ghorai et al. 2009). The aroma of wines can be improved through modifying glycosylated precursors by $\beta-$ glucosidases. Using macerating enzymes to treat grapes for wine fermentation also strengthens the ability of press, settling and juice yields. Cellulases, hemicellulases, galactomannanase, and pectinases are also used in the coffee industry. Enzymes are used from microbial sources such as Leuconostoc mesenteroides, Saccharomyces marscianus, Flavobacterium spp., and Fusarium spp. (Binod et al. 2008). Alpha and $\beta$-amylase, phospholipase, pullulanase and invertase are used in production of various types of syrups from starch and sucrose and help with product shelf life (Patel et al. 2016).

\section{Pulp and paper industry}

(1) Delignification of lignocelluloses

In paper production it is necessary to separate lignin from cellulose fibers, so chlorine, sulphite and oxygen-based oxidants have been widely used. However, these substances are damaging to the environment and they have been replaced by laccase (Kristensen et al. 2008).

(2) Biopulping and biobleaching

Biopulping is the enzymatic pretreatment of wood chips before chemical methods. Chemical bleaching is a fast process but it affects the cellulose in the pulp and the environment is also polluted by various effluents from paper plants. Ligninolytic enzymes are able to delignify and bleach pulp. Although this process is rather slow compared with chemical bleaching, it is an eco-friendly method (Ana et al. 2007). Hakala et al. (2004) chose 86 fungal strains for wood block decay test. Of these, Physisporinus rivulosus T241i was the best choice for softwood biopulping application. Behrendt \& 
Blanchette (1997) used Phlebiopsis gigantean to treat wood logs and found that the wood pitch content reduction was promoted, chemical pulping was easier, there was refining energy saving, and better wood ingrain.

Table 3 Advantages and disadvantages of Solid state fermentation over Submerge fermentation (Pérez et al. 2003)

\section{Advantages}

Disadvantages

- Similar or higher yields

- Simple culture media. The substrate usually provides all the nutrients necessary for growth

- Low chance of contamination by bacteria and yeast. This allows working in aseptic conditions in some cases

- Similar to natural habitats for fungi

- Aerification area is high

- In case of fungi, inoculation with spores is possible

- Simple design reactors with few spatial requirements can be used due to the concentrated nature of the substrates

- Low energy consumption in case of vapor treatment, mechanical agitation and aeration are not necessary

- Less need for product extraction due to its high concentration. Small volumes of polluting effluents.

- Low moisture availability may favour production of specific compounds that may not be produced or may be poorly produced in $\mathrm{SmF}$

- In some cases, the products obtained have slightly different properties (e.g. more thermotolerance)

- Due to concentrated nature of substrate, smaller reactors can be used to hold the same amounts of substrate
- Only suitable for microorganisms that require low level of water

- Substrates require physical pre-treatment

- Biomass determination is very difficult

- Difficult to monitor process parameters such as $\mathrm{pH}$, moisture content, and substrate, oxygen and biomass concentration

- Difficult in agitation (static conditions are preferred)

- Spores have longer lag times due to need for germination

- High inoculum volumes are needed

- Many important basic scientific and engineering aspects are poorly characterized. Information about design and operation of reactors on a large scale is scarce

- Contamination by undesirable fungi could happen

- May cause difficulty if metabolic heat generated during growth not removed

- Extracts containing products obtained by leaching of fermented solids are often of viscous nature

- Mass transfer limited to diffusion

- Cultivation times are longer 


\section{Textile industry}

(1) Dye decolourization

The textile industry has a bad reputation as an environmental polluter. Textile waste waters contain various dyes that are hardly decolorized by conventional treatment systems and cause high biological oxygen demand (BOD) and chemical oxygen demand (COD) (Nagaraj \& Kumar 2006). Using biological techniques to decolour dye is cost effective and has application for a wide range of dyes. For example, ligninolytic enzymes such as azoreductase, laccases, peroxidases, and polyphenoloxidase can be used to decolorize dyes in waste waters (Imran et al. 2015, Singh et al. 2015).

(2) Denim finishing

In the past, fabric was washed with abrasives to produce a worn or faded appearance in denim before it was partially pre-bleached in sodium hypochlorite then neutralized in a rinsing step. This process was a major polluter of the environment. In 1996, Novozyme (Novo Nordisk, Denmark) took the initiative and "DeniLite" became the first industrial laccase and the first bleaching enzyme which acts with the help of a mediator molecule. Research in this field had led to discovering novel microorganism to produce high quality laccase under normal environmental conditions (Sharma et al. 2005).

(3) Cotton bleaching

Bleaching cotton to reject natural pigments results in flavonoids with white appearance. Hydrogen peroxide was previously used as the bleaching agent, but it damages fibers by decreasing the degree of polymerization. Enzymatic systems not only cause less damage to fibers but also minimize water use and the development of a quality product. Ligninolytic enzymes work at low concentrations without reducing the quality of the fabric (Tzanov et al. 2003). Fungal laccase from Trametes pubescen and Pycnoporus sanguineus are used in dye decolorization, cotton bleaching and textile application which could be induce the production by copper sulphate and nitrogen source (Spina et al. 2016, Iracheta et al. 2016). Recently, high frequency ultrasound in the range $850 \mathrm{kHz}$, $400 \mathrm{~W}$ has been applied to enhance the activity of laccase and to improve the whitening effectiveness (Gonçalves et al. 2014).

\section{Bio-ethanol production}

Fermentation of wood hydrolysates is an essential product for fuel ethanol. Plant cell walls generally constitute 15-40\% cellulose, 10-30\% hemicellulose and pectin, and 5-20\% lignin (Prassad et al. 2007); these are the initial substances for microbes to hydrolyze and can be derived to produce bio-ethanol. The problem of running out of oil, gas and coal and the environmental impacts of fossil fuels is of serious concern (Sun \& Cheng 2002). Cellulose hydrolysis occurs on the substrates and endoglucanases are involved. As is well known, white-rot fungi have the capability to degrade lignin (Eriksson et al. 1990). One of the best white-rot fungi is the polypore, Trametes versicolor. It secretes enzymes such as phenol oxidase, laccase and perioxidase, which take part in the transformation of aromatic compounds (Lipin et al. 2013). Recently, many fungi have shown efficiency for use as bioethanol production by utilizing wastes. These include Aspergillus niger (Izmirlioglu et al. 2016), Ganoderma lucidum (Bilal et al. 2015), and Fusarium sp., Spicaria sp., Rhizoctonia sp., and Paecilomyces sp. (Dar et al. 2016).

\section{Food processing industry}

There are numerous applications for using cellulases in food biotechnology. For example, fruit and vegetable juice production requires cellulases to improve extraction methods, clarification, and stabilization, and also xylanases and pectinases have an important application to increase the yield of juices as part of a macerating enzymes complex (Minussi et al. 2002, Carvalho et al. 2008). Enzyme mixtures containing pectinases, cellulases, and hemicellulases are also used for improved extraction of olive oil. Use of macerating enzymes not only improves the cloud stability and texture of nectars and purees, but also rapidly decreases their viscosity (Grassin \& Fauquembergue 1996). 


\section{Animal feed and agricultural industries}

Enzymes were first used commercially in animal feed in Finland in the 1980s. Applications of cellulolytic enzymes can improve nutritional value and absorbence (Dhiman et al. 2002). In feed industry, $\beta$-glucanases and xylanases are used to hydrolyze non-starch polysaccharides. By improving digestion and absorption of feed materials, cellulase can significantly improve quality of meat and also weight gain in chickens and piglets (Ramesh et al. 2011). Enzyme use in animal nutrition has become essential following the prohibition of using some food supplements and antibiotics in feed animal product in EU countries (Ali et al. 1995). Many producers supplement feed with enzyme additives to improve the efficiency, decrease the volume of manure produced, reduce cost, lower phosphorus and nitrogen excretion, improve consistency and to help maintain gut health (Michael \& Gary 2010). Phytase plays an important role in release of phosphate from phytate, enhancing digestibility. For example, monogastric animals cannot break down the phytate molecules in many plant tissues, such as bran, seeds, cereals and grains to generate phosphorus, which is a key nutritional requirement for animals to provide bone growth. Thus, phytases have been used for animal feed and this has been commercialized in recent years (Blackburn et al. 2015). Lignocellulolytic enzymes consisting of various composition from ligninolytic and cellulolytic have been also tested for enhancing growth of crops and controlling plant pathogens (Ramesh et al. 2011).

\section{Oil extraction}

Enzyme treatment is probably the most important in oil extraction as it digests the complex cell wall of oil seeds, altering permeability favoring oil extraction. Enzymes enhance extraction and separation process, eliminate toxic anti-nutritional factors, catalyse carbohydrate, protein and lipid conversion through their antioxidant and biocatalytic activities (Kalia et al. 2001). Enzymes are applied in various oil seed materials such as peanut, sunflower, soybean, grape seed, etc. Using macerating enzymes during olive oil extraction can increase levels of antioxidants and vitamin $\mathrm{E}$ extraction (up to $2 \mathrm{~kg}$ oil per $100 \mathrm{~kg}$ olives) under cold processing conditions. Enzymes also hold back induction of rancidity and oil content in the waste water (Galante et al. 1998). Using enzymes in sunflower oil extraction with non-toxic as solvent showed the highest capacity on antioxidant against peroxyl radicals, total phytosterols and omega-3 fatty acids contents, as well as the lowest content of saturated fatty acids, when compared with the oil obtained by conventional methods (Suellen et al. 2016). Interestingly, fungi could be the new representative in developments of biodiesel production using fungal lipases (Aguieiras et al. 2015).

\section{Acknowledgements}

This research was financially supported by Center of Excellence on Biodiversity (BDC), office of higher education commission (BDC-PG2-159013) and TRF Research-Team Association Grant (RTA5880006). The authors are also grateful to Dr. Eric McKenzie of Landcare Research, New Zealand and Dr. Watsana Penkhrue of Sustainable Development of Biological Resources Laboratory - Chiang Mai University, Thailand for valuable comments. Graduate School of Chiang Mai University is thanked for trainee scholarship.

\section{References}

Afzal A, Kamran M, Mehmood S, Irshad M. 2014 - Induced production of exoglucanase, and $\beta$ glucosidase from fungal co-culture of T. viride and G. lucidum. Advances in Bioscience and Biotechnology 5(5), 426-433.

Agrawal N, Verma P, Singh RS, Shahi SK. 2017 - Ligninolytic enzyme production by white rot fungi Podoscypha elegans strain FTG4. International Journal of Current Microbiology and Applied Sciences 5, 2757-2764.

Aguieiras EC, Ribeiro DS, Couteiro PP, Bastos CM et al. 2015 - Investigation of the reuse of immobilized lipases in biodiesel synthesis: influence of different solvents in lipase activity. Applied Biochemistry and Biotechnology 179(3), 485-496. 
Ali S, Hall J, Soole KL, Fontes CMGA et al. 1995 - Targeted expression of microbial cellulases in transgenic animals. Progress in Biotechnology 10, 279-293.

Amorim GM, Oliveira AC, Gutarra ML, Godoy MG, Freire DM. 2017 - Solid-state fermentation as a tool for methylxanthine reduction and simultaneous xylanase production in cocoa meal. Biocatalysis and Agricultural Biotechnology 11, 34-41.

Ana MRBX, Ana PMT, Rita F, Francisco A. 2007 - Trametes versicolor growth and laccase induction with by-products of pulp and paper industry. Journal of Biotechnology 10(3), 444451.

Bajpai P. 2016 - Structure of lignocellulosic biomass, pretreatment of lignocellulosic biomass for biofuel production. Https://www.springer.com (accessed 14 April 2018).

Barrios GJ. 2012 - Solid-state fermentation: physiology of solid medium, its molecular basis and applications. Process Biochemistry 47, 175-185.

Behnam S, Karimi K, Khanahmadi M, Salimian Z. 2016 - Optimization of xylanase production by Mucor indicus, Mucor hiemalis, and Rhizopus oryzae through solid state fermentation. Biological Journal of Microorganism 4(16), 1-10.

Behrendt CJ, Blanchette RA. 1997 - Biological processing of pine logs for pulp and paper production with Phlebiopsis gigantea. Applied and Environmental Microbiology 63, 1995-2000.

Bharathiraja S, Suriya J, Krishnan M, Manivasagan P, Kim SK. 2017 - Production of enzymes from agricultural wastes and their potential industrial applications. Advances in Food and Nutrition Research 80, 125-148.

Bilal M, Asgher M, Ramzan M. 2015 - Purification and biochemical characterization of extracelular manganese peroxidase from Ganoderma lucidum IBL-05 and its application. Scientific Research and Essays 10, 456-464.

Binod P, Singhania RR, Soccol CR, Pandey A. 2008 - Industrial enzymes. Advances in fermentation technology. Https://books.google.co.th (accessed 14 April 2018).

Bisht M, Rathi N, Rai JPN. 2017 - Importance of lignin modifying enzymes from isolated white rot fungus in lignin degradation. International Journal of Innovative Research in Science, Engineering and Technology 6, 2347-6710.

Blackburn MD, Gabler S, Greiner R. 2015 - Performance of seven commercial phytases in an in vitro simulation of poultry digestive tract. Journal of Agricultural and Food Chemistry 63, 6142-6149.

Bouacem K, Rekik H, Jaouadi NZ, Zenati B et al. 2018 - Purification and characterization of two novel peroxidases from the dye-decolorizing fungus Bjerkandera adusta strain CX-9. International Journal of Biological Macromolecules 106, 636-646.

Bourbonnais R, Paice MG, Reid ID, Lanthier P, Yaguchi M. 1995 - Lignin oxidation by laccase isozymes from Trametes versicolor and role of the mediator 2, 2'-azinobis (3ethylbenzthiazoline-6-sulfonate) in kraft lignin depolymerization. Applied and Environmental Microbiology 61(5), 1876-1880.

Bourbonnais R, Paice MG. 1990 - Oxidation of non-phenolic substrates. An expanded role for laccase in lignin biodegradation. FEBS Letters 267(1), 99-102.

Bourquelot, Herissey. 1897 - Ueber die Hydrolyse der melezitose durch losliche fermente. Chemistry Central Journal 1, 1-30.

Carvalho DLMJ, Castro DIM, Silva DCAB. 2008 - A study of retention of sugars in the process of clarification of pineapple juice (Ananas comosus, L. Merril) by micro- and ultra-filtration. Journal of Food Engineering 87(4), 447-454.

Castro DAM, Pereira PNJR. 2010 - Propriedades e aplicação de celulases na hidrólise de resíduos agroindustriais. Química Nova 33, 181-188.

Chairin T, Nitheranont T, Watanabe A, Asada Y et al. 2013 - Biodegradation of bisphenol A and decolorization of synthetic dyes by laccase from white-rot fungus, Trametes polyzona. Applied Biochemistry and Biotechnology 169(2), 539-545. 
Chairin T, Nitheranont T, Watanabe A, Asada Y et al. 2014 - Purification and characterization of the extracellular laccase produced by Trametes polyzona WR710-1 under solid-state fermentation. Journal of Basic Microbiology 54(1), 35-43.

Chandrasrikul A, Suwanarit P, Sangwanit U, Lumyong S et al. 2011 - Checklist of Mushrooms (Basidiomycetes) in Thailand. Office of Natural Resources and Environmental Policy and Planning, Bangkok, Thailand. Http://chm-thai.onep.go.th (accessed 14 April 2018).

Chanwicha N, Katekaew S, Aimi T, Boonlue S. 2015 - Purification and characterization of alkaline xylanase from Thermoascus aurantiacus var. levisporus KKU-PN-I2-1 cultivated by solidstate fermentation. Mycoscience 56(3), 309-318.

Chinedu SN, Okochi V, Smith H, Omidiji O. 2005 - Isolation of cellulolytic micro-fungi involved in wood-waste decomposition: Prospects for enzymatic hydrolysis of cellulosic wastes. International Journal of Biomedical and Health Sciences 1(2), 0794-4748.

Chuwech M, Nuansri R. 2015 - Potential of peanut hulls as substrates for fungal cellulase bioproduction through solid state fermentation. KKU Research Journal 19, 235-243.

Couto SR, Toca HJL. 2006 - Industrial and biotechnological applications of laccases: a review. Biotechnology Advances 24(5), 500-513.

Dar B, Kyu TM, Thein SS, Nyunt SK et al. 2016 - Preparation of cellulase enzyme and bio-ethanol production from agricultural waste product. Universities' Research Centre Collection. Http://uyr.uy.edu.mm (accessed 14 April 2018).

Davin LB, Lewis NG. 2005 - Lignin primary structures and dirigent sites. Current Opinion in Biotechnology 16, 407-415.

Delabona PDS, Deise JL, Diogo R, Sarita CR et al. 2016 - Enhanced cellulase production by Trichoderma harzianum by cultivation on glycerol followed by induction on cellulosic substrates. Journal of Industrial Microbiology \& Biotechnology 43, 617-626.

Dhillon GS, Oberoi HS, Kaur S, Bansal S, Brar SK. 2011 - Value-addition of agricultural wastes for augmented cellulase and xylanase production through solid-state tray fermentation employing mixed-culture of fungi. Industrial Crops and Products 34(1), 1160-1167.

Dhiman TR, Zaman MS, Gimenez RR, Walters JL, Treacher R. 2002 - Performance of dairy cows fed forage treated with fibrolytic enzymes prior to feeding. Animal Feed Science and Technology 101(1-4), 115-125.

Duenas FRJ, Taina L, Dimitrios F, Laszlo NGB et al. 2013 - Lignin-degrading peroxidases in Polyporales: an evolutionary survey based on 10 sequenced genomes. Mycologia 105(6), 1428-1444.

Eichlerová I, Homolka L, Benada O, Kofronova O et al. 2007 - Decolorization of orange G and remazol brilliant blue R by the white rot fungus Dichomitos squalens: toxicological evaluation and morphological study. Chemosphere 69(5), 795- 802.

Elisashvili V, Kachlishvili E, Asatiani MD, Darlington R, Kucharzyk KH. 2017 - Physiological peculiarities of lignin-modifying enzyme production by the white-rot basidiomycete Coriolopsis gallica strain BCC 142. Microorganisms 5(4), 1-73.

Eriksson KEL, Blanchette RA, Ander P. 1990 - Microbial and enzymatic degradation of wood and wood components. http://cmu.worldcat.org (accessed 14 April 2018).

Farradá GT, León AMM, Rineau F, Alonso LLL et al. 2017 - Diversity of ligninolytic enzymes and their genes in strains of the genus Ganoderma: applicable for biodegradation of xenobiotic compounds? Frontiers in Microbiology 8(898), 1-16.

Floudas D, Binder M, Riley R, Barry K et al. 2012 - The Paleozoic origin of enzymatic lignin decomposition reconstructed from 31 fungal genomes. Science 336, 1715-1719.

Galante YM, Conti DA, Monteverdi R. 1998 - "Application of Trichoderma enzymes in food and feed industries" in Trichoderma and Gliocladium. Enzymes, Biological Control and Commercial Applications 2, 311-326.

Ghorai S, Banik SP, Verma D, Chowdhury S et al. 2009 - Review fungal biotechnology in food and feed processing. Food Research International 42(5-6), 577-587.

Ghose TK, Bisaria VS. 1979 - Studies on the mechanism of enzymatic hydrolysis of cellulosic 
substances. Biotechnology and Bioengineering 21, 131-146.

Gianfreda L, Xu F, Bollag JM. 1999 - Laccases: a useful group of oxidoreductive enzymes. Bioremediation Journal 3(1), 1-25.

Ginns J. 2017 - Polypores of British Columbia (Fungi: Basidiomycota). Technical Report 104, 1256.

Glenn JK, Gold MH. 1985 - Purification and characterization of an extracellular Mn(II) - dependent peroxidase from the lignin-degrading basidiomycete, Phanerochaete chrysosporium. Archives of Biochemistry and Biophysics 242, 329-341.

Gonçalves I, Martins M, Loureiro A, Gomes A et al. 2014 - Sonochemical and hydrodynamic cavitation reactors for laccase/hydrogen peroxide cotton bleaching. Ultrasonics Sonochemistry 21(2), 774-781.

Grassin C, Fauquembergue P. 1996 - Fruit juices. Industrial Enzymology 2, 225-264.

Gupta VK. 2016 - New and future developments in microbial biotechnology and bioengineering, microbial cellulase system properties and applications. Elsevier Chapter 14, 165 - 173.

Hakala TK, Maijala P, Konn J, Hatakka A. 2004 - Evaluation of novel wood rotting polypores and corticioid fungi for the decay and bio-pulping of Norway spruce (Picea abies) wood source. Enzyme Microbial Technology 34, 255-263.

Hammel KE, Jensen KA, Mozuch MD, Landucci LL et al. 1993 - Ligninolysis by a purified lignin peroxidase. The Journal of Biological Chemistry 268, 12274-12281.

Han X, Liu G, Song W, Qin Y, Qu Y. 2017 - Continuous feeding of spent ammonium sulphite liquor improves the production and saccharification performance of cellulase by Penicillium oxalicum. Bioresource Technology 245, 984-992.

Hans ES, Klaus P. 1996 - On the interaction of lignin peroxidase with lignin. Pure and Applied Chemistry 68(11), 2089-2096.

Hatakka A. 1994 - Lignin-modifying enzymes from selected white-rot fungi: production and role in lignin degradation. FEMS Microbiology Reviews 13, 125-135.

Henrissat B. 1991 - A classification of glycosyl hydrolases based on amino acid sequence similarities. Biochemical Journal 280(2), 309-316.

Hesseltine CW. 1977 - Solid state fermentation part1. Process Biochemistry 1, 24-27.

Holker U, Hofer M, Lenz J. 2004 - Biotechnological advantages of laboratory-scale solid-state fermentation with fungi. Applied Microbiology and Biotechnology 64, 175-186.

Imran M, Crowley DE, Khalid A, Hussain S et al. 2015 - Microbial technology for decolorization of textile wastewaters. Reviews in Environmental Science and Bio/Technology 14, 73-92.

Iracheta CMM, Rocha PMA, Galán WLJ, Arévalo NK, Tovar HOE. 2016 - A Pycnoporus sanguineus laccase for denim bleaching and its comparison with an enzymatic commercial formulation. Journal of Environmental Management 177, 93-100.

Isikgora FH, Becer CR. 2015 - Lignocellulosic biomass: a sustainable platform for the production of bio-based chemicals and polymers. Polymer Chemistry 6, 4497-4559.

Izmirlioglu G, Demirci A. 2016 - Strain selection and medium optimization for glucoamylase production from industrial potato waste by Aspergillus niger. Journal of the Science of Food and Agriculture 96(8), 2788-2795.

Jaana K, Miia MR, Jarkko I, Ilona O, Taina L. 2015 - Lignocellulose-converting enzyme activity profiles correlate with molecular systematics and phylogeny grouping in the incoherent genus Phlebia (Polyporales, Basidiomycota). BMC Microbiology 15(217), 1-18.

Jang Y, Jang S, Lee J, Lee H et al. 2014 - Wood decay fungi in South Korea: Polypores from Seoul. Microbiology 42(2), 140-146.

Jayachandran M, Xiao J, Xu B. 2017 - A critical review on health promoting benefits of edible mushrooms through gut microbiota. International Journal of Molecular Sciences 18(1934), 112.

Ji XH, Thawthong A, Wu F. 2017 - A new species of Perenniporia (Polyporales, Basidiomycota) from Thailand. Mycosphere 8(8), 1102-1107.

Jo WS, Park HN, Cho DH, Yoo YB, Park SC. 2011 - Optimal media conditions for the detection of 
extracellular cellulase activity in Ganoderma neo-japonicum. Mycobiology 39(2), 129-132.

Kabenge I, Omulo G, Banadda N, Seay J et al. 2018 - Characterization of banana peels wastes as potential slow pyrolysis feedstock. Journal of Sustainable Development 11, 14-24.

Kadri T, Rouissi T, Brar SK, Cledon M et al. 2017 - Biodegradation of polycyclic aromatic hydrocarbons (PAHs) by fungal enzymes: a review. Journal of Environmental Sciences 51, 5274.

Kalia VC, Rashmi, Sadhana L. 2001 - Using enzymes for oil recovery for edible seeds. Journal of Scientific and Industrial Research 60, 298-310.

Kandasamy S, Muniraj IK, Purushothaman N, Sekar A et al. 2016 - High level secretion of laccase $(\mathrm{LccH})$ from a newly isolated white-rot Basidiomycete, Hexagonia hirta MSF2. Frontiers in Microbiology 7(707), 1-12.

Kantharaj P, Boobalan B, Sooriamuthu S, Mani R. 2017 - Lignocellulose degrading enzymes from fungi and their industrial applications. International Journal of Current Research and Review 9, 2231-2196.

Khushal B, Anne R, Praveen VV. 2010 - Fungal laccases: production, function, and applications in food processing. Enzyme Research 2010 (149748), 1-10.

Kim D, Orrego D, Ximenes EA, Ladisch MR. 2017 - Cellulose conversion of corn pericarp without pretreatment. Bioresource Technology 245, 511-517.

Kim D, Ximenes EA, Nichols NN, Cao G et al. 2016 - Maleic acid treatment of biologically detoxified corn stover liquor. Bioresource Technology 216, 437-445.

Kim S. 2018 - Evaluation of alkali-pretreated soybean straw for lignocellulosic bioethanol production. International Journal of Polymer Science 2018, 1-7.

Kozue S, Toshinori M, Tadamori A, Sophon B. 2016 - Polyporus thailandensis, a new species of group Polyporellus in Polyporus (Polyporales, Agaricomycota) from Northeastern Thailand. Mycoscience 57 (2), 85-89.

Kristensen JB, Thygesen LG, Felby C, Jorgensen H, Elder T. 2008 - Cellwall structural changes in wheat straw pretreated for bioethanol production. Biotechnology Biofuels 1(5), 1-9.

Kuhara F, Papinutti L. 2014 - Optimization of laccase production by two strains of Ganoderma lucidum using phenolic and metallic inducers. Revista Argentina de Microbiologia 46(2), 144149.

Kumar AK, Sharma S. 2017 - Recent updates on different methods of pretreatment of lignocellulosic feedstocks: a review. Bioresources and Bioprocessing 4(7), 1-19.

Kuuskeri J, Mäkelä MR, Isotalo J, Oksanen I, Lundell T. 2015 - Lignocellulose-converting enzyme activity profiles correlate with molecular systematics and phylogeny grouping in the incoherent genus Phlebia (Polyporales, Basidiomycota). BMC Microbiology 15(217), 1-18.

Levin L, Papinutti L, Forchiassin F. 2004 - Evaluation of Argentinean white rot fungi for their ability to produce lignin-modifying enzymes and decolorize industrial dyes. Bioresource Technology 94, 169-176.

Levin L, Villalba L, Da RV, Forchiassin F, Papinutti L. 2007 - Comparative studies of loblolly pine biodegradation and enzyme production by Argentinean white rot fungi focused on biopulping processes. Process Biochemistry 42, 995-1002.

Lipin D, Mundur S, Chandra SM, Thankamani V. 2013 - Ligninolytic enzymes for application in treatment of effluent from pulp and paper industries. Journal of Environmental Research and Technology 1, 14-26.

Liwei Z, Yucheng D. 2013 - Chinese polypore diversities: species, mycota and ecological functions. Biodiversity Science 21(4), 499-506.

Maheshwari R, Bharadwaj G, Bhat MK. 2000 - Thermophilic fungi: their physiology and enzymes. Microbiology and Molecular Biology Reviews 64, 461-488.

Mali T, Kuuskeri J, Shah F, Lundell TK. 2017 - Interactions affect hyphal growth and enzyme profiles in combinations of coniferous wood-decaying fungi of Agaricomycetes. PLoS ONE 12(9), 1-21. 
Melo EB, Silveira DG, Carvalho I. 2006 - $\alpha$-and $\beta$-Glucosidase inhibitors: chemical structure and biological activity. Tetrahedron 62(44), 10277-10302.

Metrevelia E, Kachlishvilia E, Singer SW, Elisashvili V. 2017 - Alteration of white-rot basidiomycetes cellulase and xylanase activitiesin the submerged co-cultivation and optimization of enzyme production by Irpex lacteus and Schizophyllum commune. Bioresource Technology 241, 652-660.

Michael RB, Gary GP. 2010 - Enzyme in farm animal nutrition $2^{\text {nd }}$ edited. Https://www.pdfdrive.com (accessed 14 April 2018)

Minussi RC, Pastore GM, Duran N. 2002 - Potential applications of laccase in the food industry. Trends in Food Science and Technology 13(6-7), 205-216.

Morozova OV, Shumakovich GP, Gorbacheva MA, Shleev SV, Yaropolov AI. 2007 - "Blue" Laccases. The Journal of Biochemistry 72(10), 1136-1150.

Mtui GYS. 2012 - Lignocellulolytic enzymes from tropical fungi: Types, substrates and applications. Scientific Research and Essays 7(15), 1544-1555.

Nagaraj CM, Kumar A. 2006 - Distillery waste water treatment and disposal. https://www.environmental-expert.com/resulteacharticle4.asp (accessed 14 April 2018).

Nair SG, Shashidhar S. 2008 - Fungal xylanase production under solid state and submerged fermentation conditions. African Journal of Microbiology Research 2(4), 82-86.

Niladevi K, Singh NNP, Pandey A. 2009 - Biotechnology for agro-industrial residues utilisation. https://www.springer.com (accessed 14 April 2018).

Nyanhongo GS, Gomes J, Gübitz GM, Zvauya R et al. 2002 - Production of laccase by a newly isolated strain of Trametes modesta. Bioresource Technology 84, 259-263.

Osma JF, Moilanen U, Toca-Herrera JL, Couto SR. 2011 - Morphology and laccase production of white-rot fungi grown on wheat bran flakes under semi-solid-state fermentation conditions. FEMS Microbiology Letters 318, 27-34.

Pandey A. 1992 - Recent developments in solid state fermentation. Process Biochemistry 27, 109117.

Patel H, Divecha J, Shah A. 2016 - Optimization of ethanol production from enzymatic hydrolysate of maize stover. Advances in Recycling and Waste Management 1(1), 2475-7675.

Pei Y, Li Y, Zhang Y, Yu C et al. 2016 - G-lignin and hemicellulosic monosaccharides distinctively affect biomass digestibility in rapeseed. Bioresource Technology 203, 325-333.

Pérez N, Guerra A, Torrado A, Macias CL, Pastrana L. 2003 - Environmental sciences chemistry, applied food science and technology. Electronic Journal of Environmental, Agricultural and Food Chemistry 2(343), 1573-4377.

Polizeli MLTM, Rizzatti ACS, Monti R, Terenzi HF et al. 2005 - Xylanases from fungi: properties and applications. Applied Microbiology and Biotechnology 67, 577- 591.

Ponlada P, Sehanat P, Pongtharin L, Eveleighb DE et al. 2016 - Two new records of the resupinate polypore fungi, Ceriporia cystidiata and Macrohyporia dictyopora in Thailand. Science Asia 42, 171-177.

Prassad S, Singh A, Joshi HC. 2007 - Ethanol as an alternative fuel from agricultural, industrial and urban residues. Resources, Conservation and Recycling 50, 1-39.

Putro JN, Soetaredjo FE, Lin SY, Ju YH, Ismadji S. 2016 - Pretreatment and conversion of lignocellulose biomass into valuable chemicals. RSC Advances 6, 46834-46852.

Ramesh CK, Rishi G, Ajay S. 2011 - Microbial Cellulases and Their Industrial Applications. Enzyme Research 2011(280696), 1-10.

Rana S, Kaur M. 2012 - Isolation and screening of cellulase producing microorganisms from degraded wood. International Journal of Pharmaceutical and Biological Sciences Fundamentals, 2(1), 10-15.

Riley R, Salamov AA, Brown DW, Nagy LG et al. 2014 - Extensive sampling of basidiomycete genomes demonstrates in adequacy of the white-rot/brown-rot paradigm for wood decay fungi. Proceedings of the National Academy of Sciences of the United States of America 111, 9923 9928. 
Robinson PK. 2015 - Enzymes: principles and biotechnological applications. Essays in Biochemistry $59,1-41$.

Robinson T, McMullan G, Marchant R, Nigam P. 2001 - Remediation of dyes in textile effluent: a critical review on current treatment technologies with a proposed alternative. Bioresource Technology 77, 247-255.

Roongsawang N, Promdonkoy P, Wongwanichpokhin M, Sornlake W et al. 2010 - Coexpression of fungal phytase and xylanase utilizing the cis-acting hydrolase element in Pichia pastoris. FEMS Yeast Research 10(7), 909-916.

Roy RV, Das M, Banerjee R, Bhowmick AK. 2006 - Comparative studies on rubber biodegradation through solid-state and submerged fermentation. Process Biochemistry 41(1), 181-186.

Santos JI, Sampedro RM, Fillat U, Oliva JM et al. 2015 - Evaluating lignin-rich residues from biochemical ethanol production of wheat straw and olive tree pruning by FTIR and 2D-NMR. International Journal of Polymer Science 2015(314891), 1-11.

Sasidhara R, Thirunalasundari T. 2014 - Lignolytic and lignocellulosic enzymes of Ganoderma lucidum in liquid medium. European Journal of Experimental Biology 4(2), 375-379.

Schoemaker HE, Harvey PJ, Bowen RM, Palmer JM. 1985 - On the mechanism of enzymatic lignin breakdown. FEBS Letters 183, 2407-2412.

Shaheena R, Asgher M, Hussaina F, Bhatti HN. 2017 - Immobilized lignin peroxidase from Ganoderma lucidum IBL-05 with improved dye decolorization and cytotoxicity reduction properties. International Journal of Biological Macromolecules 103, 57-64.

Sharma HSS, Whiteside L, Kernaghan K. 2005 - Enzymatic treatment of flax fiber at the roving stage for production of wet spun yarn. Journal of Enzyme Microbial Technology 37, 386-394.

Simeng Z, Sana R, Sacha G, David N et al. 2015 - Solid-state fermentation in multi-well plates to assess pretreatment efficiency of rot fungi on lignocellulose biomass. Microbial Biotechnology 8(6), 940-949.

Singh A, Kuhad RC, Ward OP. 2007 - Industrial application of microbial cellulases. Lignocellulose biotechnology: future prospects. I.K. International Publishing House, 345-358.

Singh LR, Singh KP, Singh PR. 2015 - Enzymatic decolorization and degradation of azo dyes - a review. International Biodeterioration \& Biodegradation 104, 10-1016.

Singhania RR, Sukumaran RK, Patel AK, Larroche C, Pandey A. 2010 - Advancement and comparative profiles in the production technologies using solid-state and submerged fermentation for microbial cellulases. Enzyme and Microbial Technology 46, 541-549.

Spina F, Junghanns C, Donelli I, Nair R et al. 2016 - Stimulation of laccases from Trametes pubescens: use in dye decolorization and cotton bleaching. Preparative Biochemistry and Biotechnology 46(7), 639-47.

Suellen AOR, Antonio EN, Ana BZ, Polyana BFB et al. 2016 - Application of enzymes in sunflower oil extraction: antioxidant capacity and lipophilic bioactive composition. Journal of the Brazilian Chemical Society 27(5), 1678-4790.

Sukarta N, Sastrawidana DK. 2014 - The use of agricultural waste to increase the production ligninolytic enzyme by fungus Polyporus sp. Open Access Library Journal 1(642),1-7.

Sun Y, Cheng J. 2002 - Hydrolysis of lignocellulosic materials for ethanol production: a review. Bioresource Technology 83(2002), 1-11.

Sundaramoorthy M, Katsuyuki K, Michael HG, Thomas LP. 1997 - Crystal structures of substrate binding site mutants of manganese peroxidase. The Journal of Biological Chemistry 272(28), 17574-17580.

Syazwanee MGMF, Shaziera AGN, Izzati MZNA, Azwady AAN, Muskhazli A. 2018 Improvement of delignification, desilication and cellulosic content availability in paddy straw via physico-chemical pretreatments. Annual Research \& Review in Biology (6), 1-11.

Teeri TT. 1997 - Crystalline cellulose degradation: New insights into the function of cellobiohydrolases. Trends in Biotechnology 15, 160-167.

Thawthong A, Hapuarachchi KK, Wen TC, Raspé O et al. 2017 - Ganoderma sichuanense (Ganodermataceae, Polyporales) new to Thailand. MycoKeys 22, 27-43. 
Thiribhuvanamala G, Kalaiselvi G, Parthasarathy S, Madhavan S, Prakasam V. 2017 - Extracellular secretion of lignocellulolytic enzymes by diverse white rot basidiomycetes fungi. Annals of Phytomedicine 1, 20-29.

Tomas V, Petr B, Gabriel J. 2012 - Extracellular enzymes of the white-rot fungus Fomes fomentarius and purification of 1,4- $\beta$-Glucosidase. Applied Biochemistry and Biotechnology 169, 100-109.

Tuomela M, Hatakka A. 2011 - Oxidative fungal enzymes for bioremediation. Comprehensive Biotechnology: Environmental Biotechnology and Safety 6, 183-196.

Tzanov T, Basto C, Gubitz GM, Cavaco PA. 2003 - Laccases to improve the whiteness in a conventional bleaching of cotton. Journal of Macromolecular Material Engineering 288, $807-$ 810.

Vaithanomsat P, Apiwatanapiwat W, Petchoy O, Chedchantand J. 2010 - Production of ligninolytic enzymes by white-rot fungus Datronia sp. KAPI0039 and their application for reactive dye removal. International Journal of Chemical Engineering 2010(162504), 1-6.

Vladimir E, Michel P, Eva K, Nino T et al. 2008 - Lentinus edodes and Pleurotus species lignocellulolytic enzymes activity in submerged and solid-state fermentation of lignocellulosic wastes of different composition. Bioresource Technology 99, 457-462.

Wikee S, Chumnunti P, Kanghae A, Chukeatirote A et al. 2017 - Lignocellulolytic capability of endophytic Phyllosticta sp. Journal of Bacteriology and Mycology 4(2), 1-7.

Wipusaree N, Sihanonth P, Piapukiew J, Sangvanich P, Karnchanatat A. 2011 - Purification and characterization of a xylanase from the endophytic fungus Alternaria alternata isolated from the Thai medicinal plant, Croton oblongifolius Roxb. African Journal of Microbiology Research 5(31), 5697-5712.

Xiao ZZ, Yi H, Percival Z. 2013 - Cellulase: Characteristics, sources, production and applications. Bioprocessing Technologies in Biorefinery for Sustainable Production of Fuels, Chemicals, and Polymers, 131-146. https://www.researchgate.net/ (accessed 09 April 2018)

Zecarias G, Duangporn P, Siripong P. 2016 - Screening of fungi producing ligninolytic enzymes by plate test technique. KKU Research Journal 22(1), 200-209.

Zhang YHP, Lynd LRA. 2006 - Functionally based model for hydrolysis of cellulose by fungal cellulase. Biotechnology and Bioengineering 94(5), 888-898.

Zhou LW, Nakasone KK, Jr HHB, Ginns J et al. 2016 - Polypore diversity in North America with an annotated checklist. Mycological Progress 15, 771-790. 